\title{
Wpływ parametrów trymowania (usuwania wypływki) na wybrane właściwości złączy zgrzewanych tarciowo
}

\author{
Influence of flash removal parameters \\ on indicated friction welded joints properties
}

\section{Streszczenie}

W artykule opisano aspekty praktyczne zgrzewania tarciowego, ze szczególnym zwróceniem uwagi na proces trymowania - obróbki ubytkowej wypływki bezpośrednio po zgrzewaniu. Na przykładach produkcyjnych wytłumaczono cel trymowania i zaprezentowano jego alternatywy. Analizowano wpływ wybranych parametrów obróbki (prędkość obrotowa, posuw oraz czas) na wybrane właściwości zgrzein tarciowych. Próbki wykonane przy zmiennych parametrach trymowania poddano badaniom wizualnym, analizie metalograficznej (makro- i mikrostruktura) oraz pomiarom twardości. Dodatkowo dla skrajnych wyników przeprowadzono analizę z wykorzystaniem kamery termowizyjnej. Na podstawie przeprowadzonych badań i testów określono wpływ parametrów obróbki na jakość zgrzein tarciowych.

Słowa kluczowe: trymowanie; zgrzewanie tarciowe; wypływka; parametry obróbki

\begin{abstract}
The practical aspects of friction welding were described in this paper including especially flash removal process occuring directly after welding. To explain the purpose of those processes the production examples and thier alternatives have been shown. The analysis has been prepared based on studies by adjusting significant process parameters (rotation speed, feedrate, time) on indicated welds properties. Samples made with variable flash removal parameters were subjected to visual tests, metallographic analysis (macroand microstructure) and hardness measurements. Additionally a thermal analysis has been prepared for extreme results. Based on described research, the influence of process parameters on the friction welds quality was determined.
\end{abstract}

Keywords: flash removal; friction welding; flash; machining parameters

\section{Wprowadzenie - aspekty praktyczne zgrzewania tarciowego w przemyśle motoryzacyjnym}

W przemyśle motoryzacyjnym wykorzystywane są liczne techniki wytwarzania elementów składowych półosi samochodowych. Jedną z nich jest proces zgrzewania tarciowego $[1 \div 10]$. Za pomocą tej technologii wytwarzane są zarówno części przegubów homokinetycznych, jak i łączące je osie. Technika ta pozwala uzyskać trwałe i funkcjonale połączenia elementów rurowych oraz prętowych, wykonanych z materiałów jedno- i różnoimiennych. W przypadku branży automotive najczęściej są to stale niskostopowe (o niskiej/średniej zawartości węgla). W zależności od konfiguracji półosi, wymagań klienta, kosztów produkcji oraz wydajności urządzeń, komponenty zgrzewane tarciowo stanowią często wybieraną alternatywę dla pozostałych technik spajania. Do największych jej zalet z pewnością należy zaliczyć stabilność samego procesu, powtarzalność wyników oraz relatywnie niski i bardzo zbliżony koszt produkcji dla wszystkich komponentów z danej rodziny $[1 \div 10]$. Proces zgrzewania tarciowego można podzielić na pięć następujących bezpośrednio po sobie etapów przedstawionych na rysunku 1.

Pierwsze cztery fazy procesu występują dla każdego produkowanego detalu, jednak ostatnia (usuniecie wypływki) stosowana jest w zależności od konfiguracji półosi. W porównaniu z innymi zabiegami stosowanymi w procesie zgrzewania tarciowego, proces usunięcia wypływki należy do najbardziej kosztownych w przeliczeniu ekonomiki produkcji na detal. W przypadku wytwarzania osi zgrzewanych łączących przeguby homokinetyczne usunięcie wypływki jest konieczne, gdy opaska chroniąca przegub jest zapinana za zgrzeiną (patrząc od strony czoła osi - rys. 2). Gdyby wypływka nie została usunięta pojawiłby się problem z montażem opaski oraz możliwość potencjalnego jej uszkodzenia (przecięcia o krawędź zgrzeiny) i wypłynięcia smaru.

Przy produkcji elementów przegubów zgrzewanych tarciowo (korpusów i tulipów), wypływka usuwana jest dla każdego detalu ze względu na późniejszy montaż łożyska

Mgr inż. Toporowski Kacper - GKN Driveline Polska Sp. z o.o., dr inż. Piwowarczyk Tomasz, prof. dr hab. inż. Ambroziak Andrzej - Politechnika Wrocławska.

Autor korespondencyjny/Corresponding author. tomasz.piwowarczyk@pwr.edu.pl 

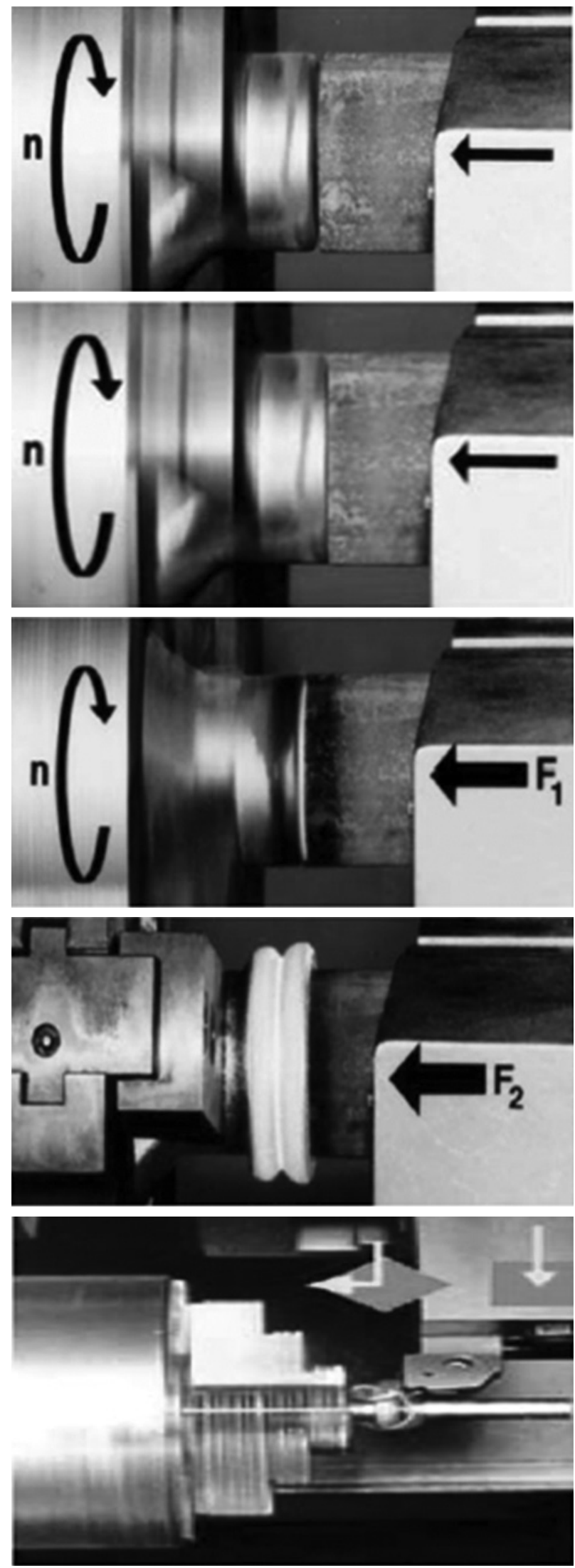

Rys. 1. Etapy procesu zgrzewania tarciowego Fig. 1. Friction welding process phases

a)

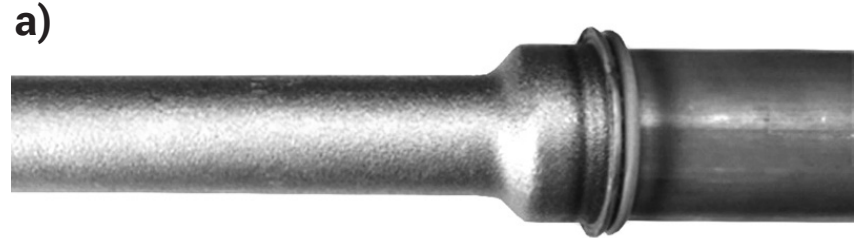

Faza 1 - pozycja początkowa:

- montaż detali (uchwyt wrzeciona + szczęki imadła)

- detal wewnątrz uchwytu wrzeciona zostaje wprawiony w ruch obrotowy

- dojazd imadła w kierunku wrzeciona

\section{Faza 2 - tarcie wstępne:}

- dochodzi do styku dwóch elementów zgrzewanych pod niskim ciśnieniem, następuje usunięcie zanieczyszczeń z powierzchni styku oraz przygotowanie do kolejnej fazy tarcia

- w tej fazie nie dochodzi do ubytku materiału

Faza 3 - tarcie właściwe (nagrzewanie i skrócenie detali):

- następuje gwałtowny wzrost ciśnienia w układzie

- wzrost temperatury zgrzeiny jest następstwem siły tarcia powstałej na powierzchni styku detali

- łączone materiały stają się plastyczne

Faza 4 - docisk:

- wrzeciono zostaje zatrzymane

- zaaplikowana siła F2 powstała na skutek wywieranego ciśnienia, większa niż siła F1, zapewnia skrócenie docisku

- następuje finalne uplastycznienie materiału

Faza 5 - usunięcie wypływki:

- imadło zostaje otworzone

- zgrzany komponent zamontowany na uchwycie wrzeciona zostaje wprawiony w ruch obrotowy

- trymer schodząc do pozycji 0 usuwa wypływkę

Rys. 2. Przykład elementu zgrzewanego tarciowo z pozostałą (a) i usuniętą wypływką (b)

Fig. 2. Example of a friction welded element with (a) and without flash (b) 


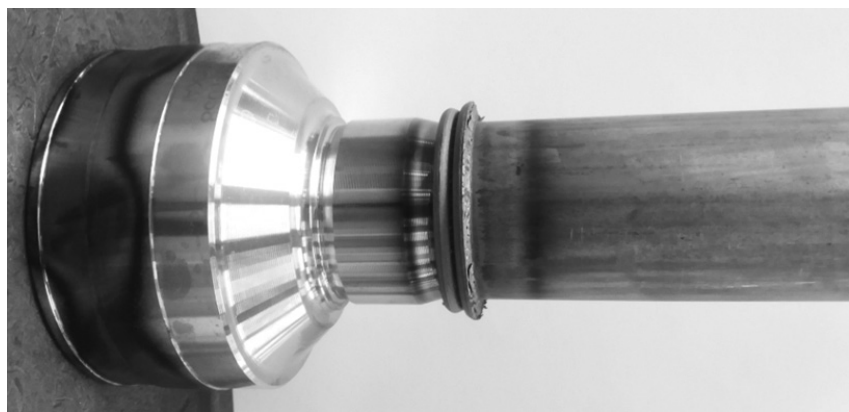

Rys. 3. Przykład korpusu zgrzewanego tarciowo z obecną wypływką Fig. 3. Example of a friction welded monoblock outerrace with flash

na średnicy położonej pomiędzy kielichem detalu a zgrzeiną (rys. 3). Obecność wypływki nie pozwala na nabicie łożyska, dlatego stosowana jest jedna z trzech metod jej usunięcia.

\section{Metody usuwania wypływki zgrzeiny}

Wybór metody usunięcia wypływki zgrzeiny poparty jest zazwyczaj analizą czynników produkcyjno-kosztowych. W przypadku produkcji na skalę masową istnieje kilka głównych czynników determinujących jej wybór. Wśród nich należy wymienić:

- możliwości przeprowadzenia zabiegu na maszynie;

- wydajność maszyn;

- wydajność pracownika/pracowników;

- koszt zabiegu na detal.

W przemyśle motoryzacyjnym wykorzystywane są głównie trzy metody ścinania zgrzeiny:

- trymowanie (usunięcie gorącej wypływki w zgrzewarce, faza nr 5 zgrzewania tarciowego, rys. 1);

- usuwanie gorącej zgrzeiny poza zgrzewarką;

- toczenie "na twardo" (zabieg wykonywany jest w późniejszej operacji toczenia).

Metoda pierwsza, nazywana branżowo trymowaniem, jest najbardziej rozpowszechniona i najczęściej stosowana. Obecnie wszystkie maszyny przeznaczone do produkcji elementów przeniesienia napędu $w$ branży automotive są wyposażone w trymer, czyli narzędzie uzbrojone w wymienną płytkę skrawającą, najczęściej wykonaną z węglika spiekanego. Zapewnia on możliwość usunięcia wypływki bezpośrednio po fazie docisku procesu zgrzewania tarciowego. Jest to zabieg najbardziej ekonomiczny (relatywnie niski koszt narzędzi), najszybszy oraz nieangażujący dodatkowych pracowników i niewymagający dodatkowych nakładów inwestycyjnych.

Stosowanie metody nr 2 - usunięcia gorącej wypływki poza zgrzewarką - związane jest z koniecznością zaangażowania dodatkowej osoby lub automatyzacją tej części procesu, co przekłada się na wydatki inwestycyjne. Wprawdzie niektóre z ww. niedogodności wykazują pewne zalety, (np. automatyzacja zwykle generuje oszczędność czasu trymowania do kilku sekund/element), ale generalnie są one obciążeniem zarówno produkcyjnym, jak i ekonomicznym. W przypadku ręcznego usuwania wypływki przez operatora, zatrudnienie dodatkowego pracownika nie będzie wymagane, gdy czas cyklu zgrzewania będzie na tyle długi, że operator zdąży wykonać czynności związane z obsługą maszyny oraz usunąć wypływkę. W praktyce produkcyjnej dzieje się to bardzo rzadko, zazwyczaj przy zgrzewaniu elementów pełnych (prętów) o dużych średnicach. Większość firm stara się ustandaryzować swoje procesy, dlatego najczęściej wybierana jest jedna metoda usuwania wypływki dla wszystkich konfiguracji z danej linii produkcyjnej lub z danego obszaru. Usuwanie ręczne wypływki wiąże się również z potencjalnym zagrożeniem BHP.
Najczęściej proces zgrzewania tarciowego nie jest operacją końcową. Występuje po nim np. obróbka cieplna czy operacja toczenia. Trzecia z metod polega na usunięciu ostudzonej do temperatury pokojowej wypływki (w zależności od materiałów wyjściowych i parametrów procesu może osiągnąć nawet do 620 HV1 [badania własne]) podczas dodatkowego zabiegu tokarskiego, który jest przeprowadzany np. za pomocą specjalnych płytek skrawających c-BN (borazon), czyli polimorficznych odmian azotku boru. W zależności od grubości detalu (lub ścianki w przypadku komponentów rurowych) oraz wynikowego skrócenia materiałów, stosowanie zabiegu toczenia może znacznie wydłużać całkowity czas operacji zgrzewania. Podczas zgrzewania tarciowego średnica wypływki może mieć nawet kilkanaście milimetrów więcej niż średnica zewnętrza wyjściowych detali zgrzewanych. Wiąże się to z koniecznością przeprowadzenia kilku przejść narzędzia podczas toczenia, co z kolei powoduje wydłużenie czasu cyklu. W związku z tym ostatnia metoda usuwania wypływki jest najdroższą z wymienionych, zarówno ze względu na koszt narzędzi, jak i wydłużony czas pracy maszyn (spadek wydajności produkcyjnej).

\section{Charakterystyka procesu trymowania}

Jak wspomniano powyżej, proces trymowania jest jedną z najczęściej wybieranych metod usuwania wypływki powstałej podczas procesu zgrzewania tarciowego. Następuje bezpośrednio po fazie docisku. Na etapy procesu trymowania składają się:

- otwarcie imadła trzymającego detal;

- odjazd imadła do pozycji bezpiecznej, ustalonej w programie dla danej referencji;

- załączenie obrotów wrzeciona;

- zejście noża do ustalonej pozycji;

- usunięcie wypływki;

- powrót noża do pozycji wyjściowej;

- zatrzymanie obrotów wrzeciona;

- zwolnienie detalu z uchwytu wrzeciona.

Można wyróżnić trzy podstawowe parametry procesu obróbki:

- prędkość obrotowa [obr/min];

- posuw noża [mm/obr] lub [bar];

- czas trymowania [s].

W większości konwencjonalnych zgrzewarek prędkość obrotowa podczas zabiegu trymowania jest stała. Zgrzewarki wyposażone są w przekładnię, która jest załączana podczas rozpoczęcia fazy nr 5 procesu zgrzewania. Nowsze maszyny posiadają płynną regulację prędkości obrotowej, co pozwala na przeprowadzenie optymalizacji procesu i uzyskanie korzystniejszych rezultatów w aspekcie żywotności narzędzi.

Posuw noża w nowszych zgrzewarkach, gdzie trymer sterowany jest numerycznie, wyrażany jest podobnie jak w przypadku tokarek jako [mm/obr], zaś w starszych modelach jako ciśnienie noża [bar], sterowany hydraulicznie na zasadzie położenia ON-OFF.

Czas trymowania odpowiada czasowi trwania zabiegu usuwania wypływki, od momentu gdy nóż dojeżdża do pozycji ustalonej jako pozycja wyjściowa, przez skrawanie właściwe, aż do momentu zakończenia procesu i powrotu narzędzia do pozycji początkowej.

Dobór podstawowych parametrów odbywa się podczas walidacji procesu tj. produkcji prototypów spełniających wszystkie wymagania geometryczne, metalograficzne i wytrzymałościowe opisane przez normy, wymagania klienta oraz dokumentację rysunkową. 


\section{Badania własne \\ - wpływ wybranych parametrów na proces trymowania}

Część badawcza obejmowała przeprowadzenie analizy wpływu poszczególnych parametrów procesu trymowania na wybrane właściwości złączy zgrzewanych tarciowo. W tablicy I przedstawiono program badań w aspekcie wybranych parametrów procesowych.

Tablica I. Wybrane parametry procesowe Table I. Selected process parameters

\begin{tabular}{|c|c|c|c|c|}
\hline Ip. & $\begin{array}{l}\text { prędkość } \\
\text { obrotowa } \\
\text { [obr/min] }\end{array}$ & $\begin{array}{c}\text { ciśnienie } \\
\text { noża [bar] }\end{array}$ & $\begin{array}{c}\text { czas trymo- } \\
\text { wania [s] }\end{array}$ & $\begin{array}{l}\text { sterowany } \\
\text { parametr }\end{array}$ \\
\hline 1 & - & - & - & $\begin{array}{c}\text { próbka } \\
\text { nominalna } \\
\text { nieobrobiona }\end{array}$ \\
\hline 2 & 800 & 60 & 3 & $\begin{array}{c}\text { próbka } \\
\text { nominalna } \\
\text { obrobiona }\end{array}$ \\
\hline 3 & 600 & 60 & 3 & \multirow{2}{*}{$\begin{array}{l}\text { prędkość } \\
\text { obrotowa }\end{array}$} \\
\hline 4 & 1000 & 60 & 3 & \\
\hline 5 & 800 & 30 & 3 & \multirow{2}{*}{$\begin{array}{l}\text { ciśnienie } \\
\text { noża }\end{array}$} \\
\hline 6 & 800 & 90 & 3 & \\
\hline 7 & 800 & 60 & 1 & \multirow{2}{*}{$\begin{array}{l}\text { czas trymo- } \\
\text { wania }\end{array}$} \\
\hline 8 & 800 & 60 & 5 & \\
\hline
\end{tabular}

Detal, dla którego wykonano pakiet badań składał się z dwóch różnoimiennych elementów rurowych (rura i odkuwka) wykonanych ze stali o zawartości węgla w zakresie $0,3 \div 0,6 \%$ i grubości ścianki $3 \mathrm{~mm}$ (gatunki stali stanowią firmowe dane poufne). Skład chemiczny rury jest bardzo podobny do składu materiału, z którego wykonano odkuwkę. Znaczącą różnicą jest większa obecność dodatku stopowego Mn oraz obecność pierwiastków takich jak Ti oraz B w materiale odkuwki. Warto zaznaczyć, że materiał ten $w$ późniejszych operacjach poddawany jest zabiegom obróbki cieplnej, w przeciwieństwie do rury, która nie jest już później obrabiana.

Wszystkie analizowane próbki wykonane zostały z zastosowaniem jednakowych parametrów zgrzewania. W celu porównania wpływu procesu trymowania na wybrane właściwości zgrzein fazy zgrzewania od 1 do 4 przebiegały w tych samych warunkach. Złącza zostały wyprodukowane w krótkich odstępach czasowych. Spektrum przygotowanych próbek podzielono na podgrupy:

- Podgrupa 1: próbki wzorcowe, 1 nieobrobiona (pominięta faza 5 zgrzewania) oraz 2 detal wyprodukowany na nominalnych parametrach trymowania, stosowanych w produkcji seryjnej;

- Podgrupa 2: sterowanie prędkością obrotową - próbki 3, 4;

- Podgrupa 3: sterowanie ciśnieniem posuwu noża - próbki 5, 6;

- Podgrupa 4: sterowanie czasem trymowania - próbki 7, 8. Analizy rozpoczęto od pomiarów rozkładu twardości wykonanych przez całą strefę złącza (materiał rodzimy 1 - SWC - zgrzeina - SWC - materiał rodzimy 2) na szerokości $10 \mathrm{~mm}$. Do badań rozkładu twardości wykorzystano pomiar metodą Vickersa przy obciążeniu $1 \mathrm{~kg}$. Poniżej za-

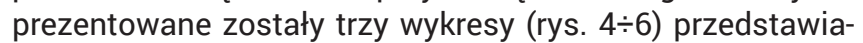
jące przebiegi twardości dla każdej z grup, w których badany był jeden z parametrów oraz jeden wykres zbiorczy (rys. 7).
Wykresy wzbogacono o wyniki dla próbek z grupy pierwszej, czyli wzorców.

Pierwszym zbadanym parametrem procesu trymowania została prędkość obrotowa n [obr/min]. Na rysunku 6 przedstawiającym wyniki dla próbek z podgrupy nr 2 można zaobserwować, że zmienność parametru nie wpływa w żaden sposób na twardość od strony rury, wszystkie cztery próbki prezentują niemalże jednakowe rezultaty. Natomiast w momencie przejścia przez środek zgrzeiny na stronę odkuwki widoczne są różnice analizowanych przebiegów. Różnica twardości pomiędzy próbkami skrajnymi (z uwzględnieniem próbki nr 1) w odległości od środka połączenia równej $0,45 \mathrm{~mm}$ (punkt drugi na rys. 4 po stronie odkuwki) wynosi 132 jednostek HV1, zaś maksymalna różnica (punkt 5 $-1,5 \mathrm{~mm})-185 \mathrm{HV} 1$. Jest to wartość duża, sugerująca możliwą zmianę struktury w tym obszarze. Różnice uwzględniające jedynie zmianę prędkości obrotowej (próbki 2, 3,4) są odpowiednio mniejsze, ale również wyraźne (67 HV1 dla punktu 2 - 0,45 mm i 96 HV1 dla punktu $5-1,5 \mathrm{~mm}$ ).

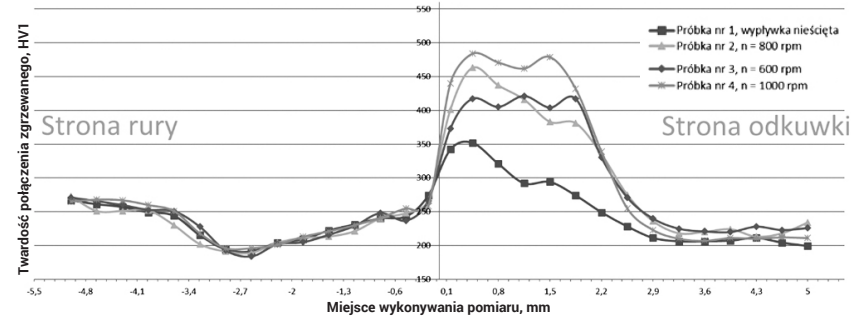

Rys. 4. Przebieg rozkładu twardości zgrzeiny dla zmiennego parametru prędkości obrotowej

Fig. 4. Weld hardness distribution for a variable rotational speed parameter

Zależności zaprezentowane na rysunku 5 przedstawiającym wyniki dla badanej podgrupy nr 3 są od strony lewej podobne jak dla podgrupy poprzedniej, tj. zmiana ciśnienia odpowiedzialnego za posuw noża nie ma wpływu na twardość materiału po stronie rury. Maksymalna różnica twardości w tym przypadku wynosząca ok. 145 HV1 dla punktów położonych najbliżej linii zgrzeiny. Jest to o ok. 40 jednostek HV1 mniej niż w podgrupie poprzedniej. Można również zaobserwować wyraźną zależność wzrostu twardości materiału po stronie odkuwki wraz ze wzrostem ciśnienia posuwu noża. Różnica otrzymanej twardości materiału w kolejnych punktach po stronie odkuwki wynosi 74 HV1 (punkt pomiarowy 1) czy 102 HV1 (punkt pomiarowy 5). Twardość maksymalna przy nastawie ciśnienia noża $\mathrm{p}=90$ bar jest największa dla wszystkich ośmiu próbek i wynosi 487 HV1, (porównywalnie z wynikiem dla próbki nr 4 - 484 HV1, rys. 4).

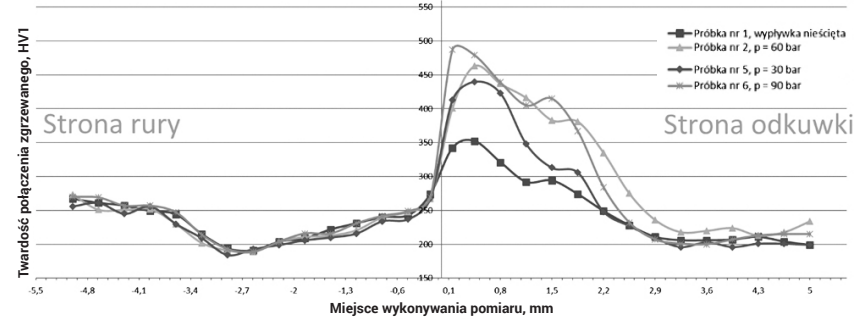

Rys. 5. Przebieg rozkładu twardości zgrzeiny dla zmiennego parametru ciśnienia posuwu noża

Fig. 5. Weld hardness distribution for the variable parameter of a tool feedrate pressure

Ostatnim z badanych parametrów był czas trymowania. Na rysunku 6 przedstawiono zbliżone wyniki dla wszystkich trzech przebiegów parametru t (próbki 2, 7, 8). Można na tej podstawie wysnuć wniosek, że zmiana czasu trymowania nie wpływa wyraźnie nie zmianę twardości obrabianych 
zgrzein. Zauważalna jest jednak różnica pomiędzy ww. próbkami a wzorcem nr 1. Wszystkie cztery przebiegi mają podobny kształt, jednak wykres twardości materiałowej dla próbki nr 1 wykazuje dla pierwszych sześciu pomiarów po stronie odkuwki wyniki średnio o ok. 90 HV1 mniejsze od pozostałych (do ok. 2,2 mm od strony połączenia).

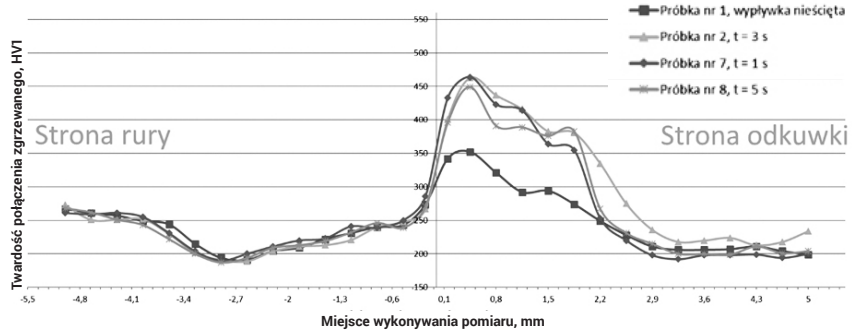

Rys. 6. Przebieg rozkładu twardości zgrzeiny dla zmiennego parametru czasu trymowania

Fig. 6. Weld hardness distribution for the variable flash removal time parameter

Na wykresie zbiorczym (rys. 7) przedstawiono wszystkie rozkłady twardości jakie otrzymano dla analizowanych ośmiu próbek. Na jego podstawie można stwierdzić, że wzrost twardości w porównaniu do próbki wzorcowej nr 1 następuje po stronie odkuwki i jest szczególnie widoczny do ok. $3 \mathrm{~mm}$ od środka połączenia. Wszystkie wyniki wykazują jednakowy przebieg przez całą zbadaną stronę rury.

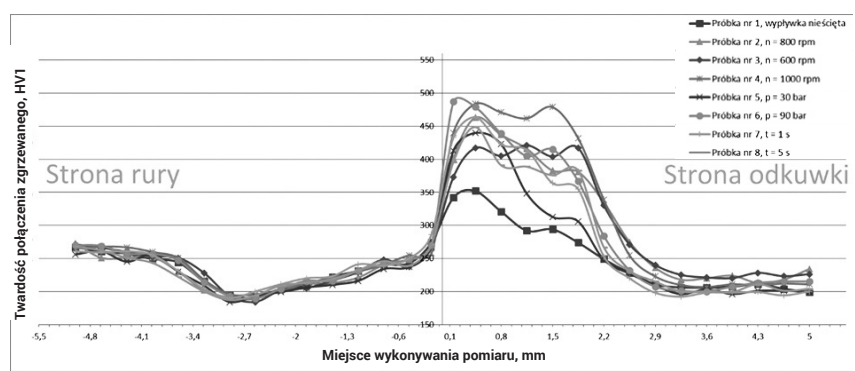

Rys. 7. Przebiegi rozkładów twardości dla wszystkich analizowanych próbek

Fig. 7. Processes of hardness distributions for all analyzed samples

Kolejne badania właściwości złączy zgrzewanych obejmowały analizę metalograficzną. Dla każdej próbki wykonano zdjęcia, przedstawiające makro- oraz mikrostrukturę materiału. Na zdjęciach (rys. 8) na górze połączenia przedstawiona jest odkuwka, poniżej - rura. Przed badaniem próbki zostały odpowiednio przygotowane (inkludowanie, szlifowanie, polerowanie, trawienie roztworem Nitalu $3 \%$ ). Obserwację makrostruktury przeprowadzono przy powiększeniu 12,5x. Wszystkie ze zbadanych próbek prezentowały zbliżone charakterystyki:

- na całej długości zgrzeiny występuje połączenie metaliczne;

- brak mikropęknięć (na rys. 8f:-8h widoczne są defekty powstałe po trawieniu);

- w strefie wypływki na rurze oraz odkuwce zaobserwowano rozrost ziarna;

- na odkuwce za SWC pojawia się miejscowo rozrost ziarna;

- ukierunkowanie włókien w strefie odkształcenia plastycznego materiału prawidłowe;

- podobna długość SWC.

Na zdjęciach makrostruktury zaznaczono obszar badanej w późniejszych etapach mikrostruktury, który dla wszystkich próbek został zlokalizowany w środku połączenia metalicznego. Sprawdzono mikrostrukturę w całym obszarze SWC, jednak z punktu widzenia badań najistotniejsze było miejsce połączenia przedstawione na rysunku 8. Badania mikrostruktury przeprowadzono przy powiększeniu 500x.
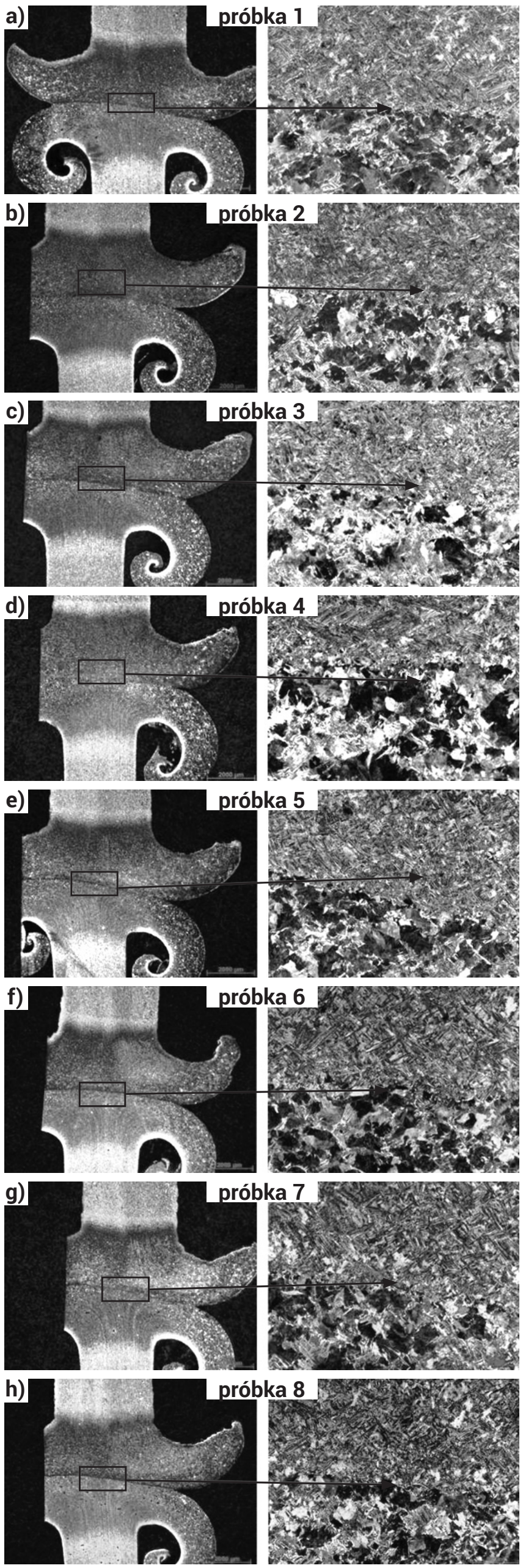

Rys. 8. Makro- i mikrostruktura badanych próbek

Fig. 8. Macro- and microstructure of tested samples 
Zbadana i opisana powyżej twardość materiału związana jest z jego mikrostrukturą. Jej wzrost jest następstwem transformacji struktury. Oznacza to, że pojawia się coraz więcej twardszych niż ferrytyczno-perlityczna struktura wyjściowa faz, w tym wypadku martenzytu i bainitu. W większości połączeń otrzymywanych metodą zgrzewania tarciowego (w zależności od procentowego udziału węgla w elementach zgrzewanych), znaczący udział twardych ziaren martenzytu w strukturze jest niedopuszczalny, ze względu na możliwość kruchego pęknięcia połączenia na skutek obniżenia wytrzymałości zmęczeniowej, która w przypadku automotive jest charakterystyką krytyczną. Struktura rury różni się od struktury odkuwki, szczególnie w badanym obszarze na środku połączenia metalicznego. Związane jest to głównie z innym składem materiałowym komponentów. Występuje tam niemal w całości struktura ferrytyczno-perlityczna, co również pokrywa się z rozkładem twardości otrzymanym dla wszystkich próbek po stronie rury, która jest mniejsza niż 300 HV1. Natomiast po stronie odkuwki występuje struktura bardziej różnorodna, zanika udział ferrytu kosztem większego udziału perlitu. Pojawiają się ziarna martenzytu i bainitu (szczególnie dla próbek z usuniętą wypływką). Na złożoność struktury ma wpływ zarówno obecność procesu trymowania, jak i jego parametry.

W celu oceny wpływu parametrów procesu trymowania na transformację mikrostruktury oraz zmianę twardości zbadano różnicę $w$ przebiegach temperatur jakie towarzyszyły procesom w dwóch skrajnych przypadkach: próbka nr 1 - wzorzec oraz próbka nr 4 - prędkość obrotowa 1000 obr/min, ciśnienie posuwu noża 60 bar, czas trymowania 3 s (próbka nr 6 wykazała największą twardość jedynie w pierwszym odcisku pomiarowym po stronie odkuwki, dlatego do badań wybrano próbkę nr 4, która w pierwszych siedmiu pomiarach wykazała największe twardości poza punktem odległym o 0,15 mm od środka połączenia).

Pomiarów dokonano za pomocą kamery termowizyjnej Flir T640, gdzie dobrano stosowny współczynnik emisyjności materiału $\varepsilon=0,80$ otrzymany podczas walidacji procesu i kalibracji kamery dla próbek zgrzewanych tarciowo [11]. Temperatura, która dla badanych próbek występuje po zakończeniu fazy docisku, osiągnęła niespełna $1100{ }^{\circ} \mathrm{C}$ (rys. 9) i jest to wyjściowa temperatura do rozpoczęcia badań nad fazą nr 5 procesu zgrzewania tarciowego. Na rysunku 10 przedstawiono przebiegi zmian maksymalnej temperatury zgrzeiny w czasie dla badanych próbek.

Rysunki 11 i 12 zostały wykonane z wykorzystaniem filtru wygaszającego wartości temperatury poniżej $100{ }^{\circ} \mathrm{C}$.

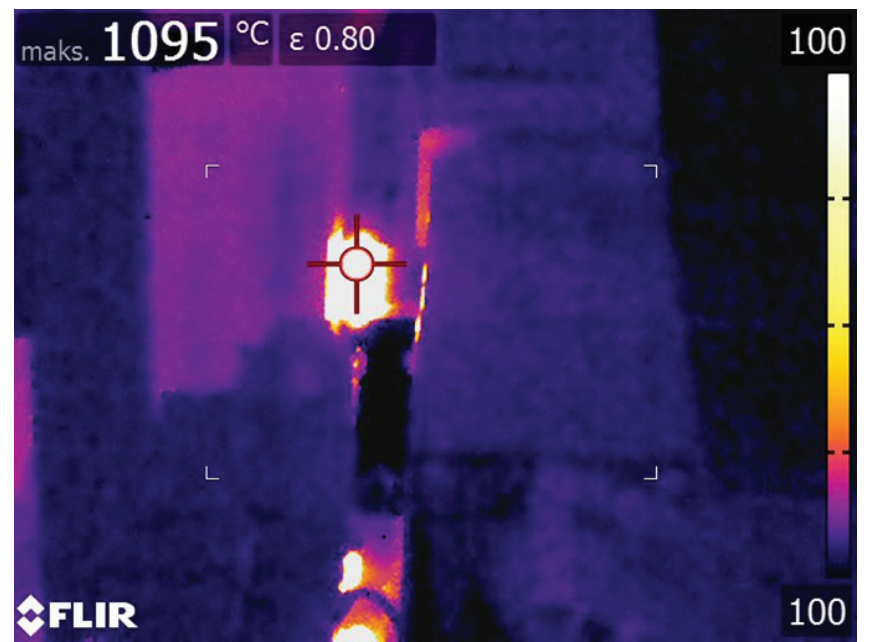

Rys. 9. Pomiar temperatury rozpoczęcia fazy 5 procesu zgrzewania tarciowego

Fig. 9. Temperature measurement result at the beginning of friction welding phase no 5

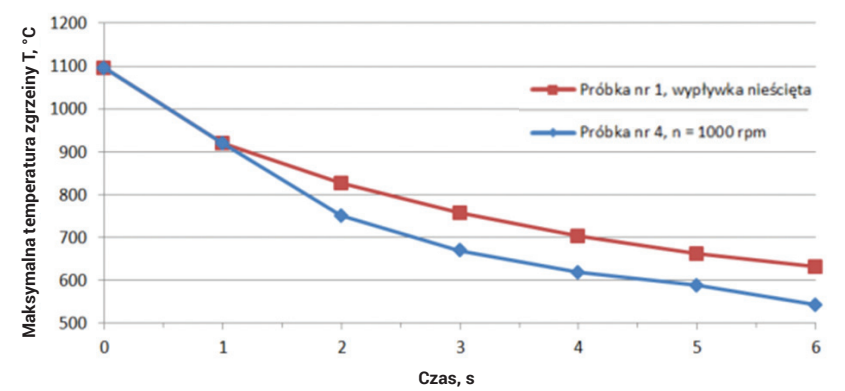

Rys. 10. Przebiegi zmian maksymalnej temperatury zgrzeiny dla badanych próbek w czasie trymowania

Fig. 10. Changes of maximum weld temperature during flash removal

Przedstawiają one otrzymane wyniki pomiarów dla badanych próbek w drugiej i piątej sekundzie cyklu trymowania. Porównując rysunki 11a i 11b można dostrzec, że styk płytki trymera (widoczny na rys. 11b) odbiera ciepło zgrzeinie. Różnica temperatur jest również widoczna na całym przebiegu przedstawionym na rysunku 10 . Od drugiej sekundy cały przebieg próbki 4 został obniżony w stosunku do przebiegu próbki 2 o wartość w przybliżeniu $80^{\circ} \mathrm{C}$. Szybkość odbieranego zgrzeinie ciepła podczas ścinania wypływki jest zależna od parametrów procesu trymowania. Na wykresie można zaobserwować, że od 2 sekundy spadek temperatur dla analizowanych próbek jest porównywalny, np. spadek temperatury $\mathrm{w}$ trzeciej sekundzie $\Delta \mathrm{t}_{3-\mathrm{p} 1}=54^{\circ} \mathrm{C}, \Delta \mathrm{t}_{3 \mathrm{~B} 4} 4=51^{\circ} \mathrm{C}$.
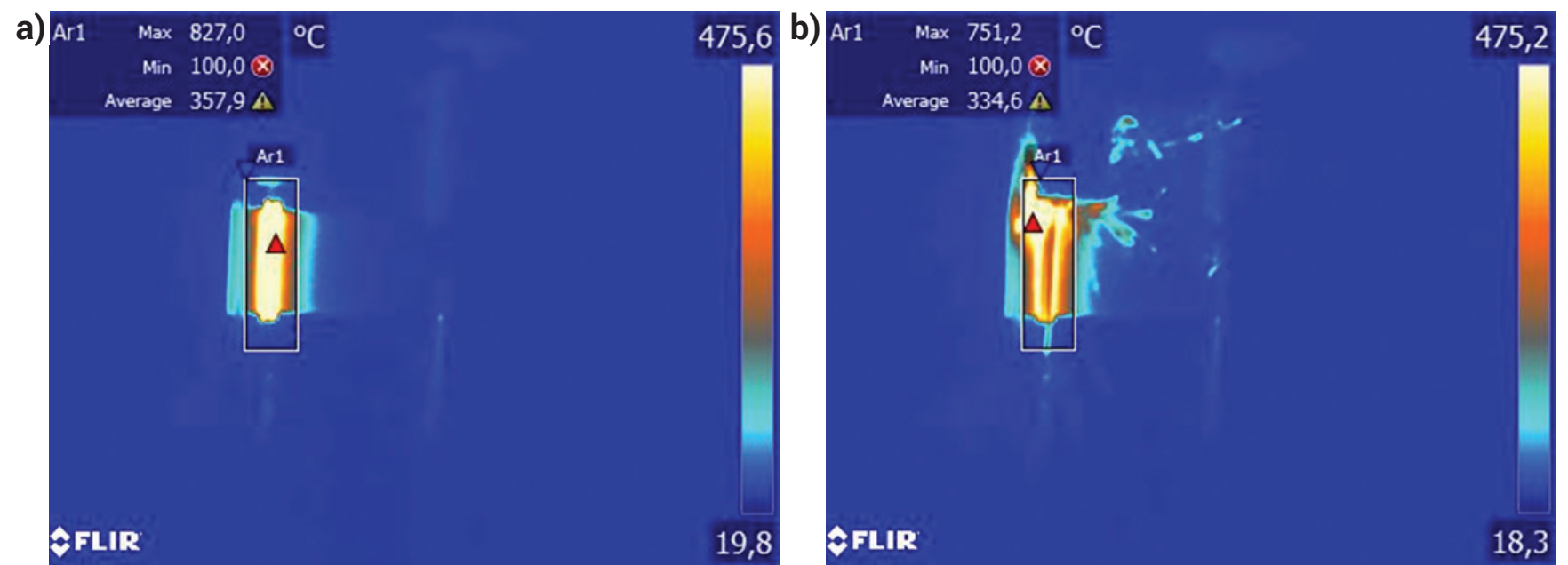

Rys. 11. Temperatura maksymalna zgrzeiny dla próbki $\mathrm{nr} 1$, czas cyklu - $2 \mathrm{~s}$ (a) i próbka nr 4, czas cyklu - $2 \mathrm{~s}$ (b)

Fig. 11. Maximum weld temperature of sample No. 1, cycle time $-2 \mathrm{~s}$ (a) and sample No. 4, cycle time $-2 \mathrm{~s}$ (b) 


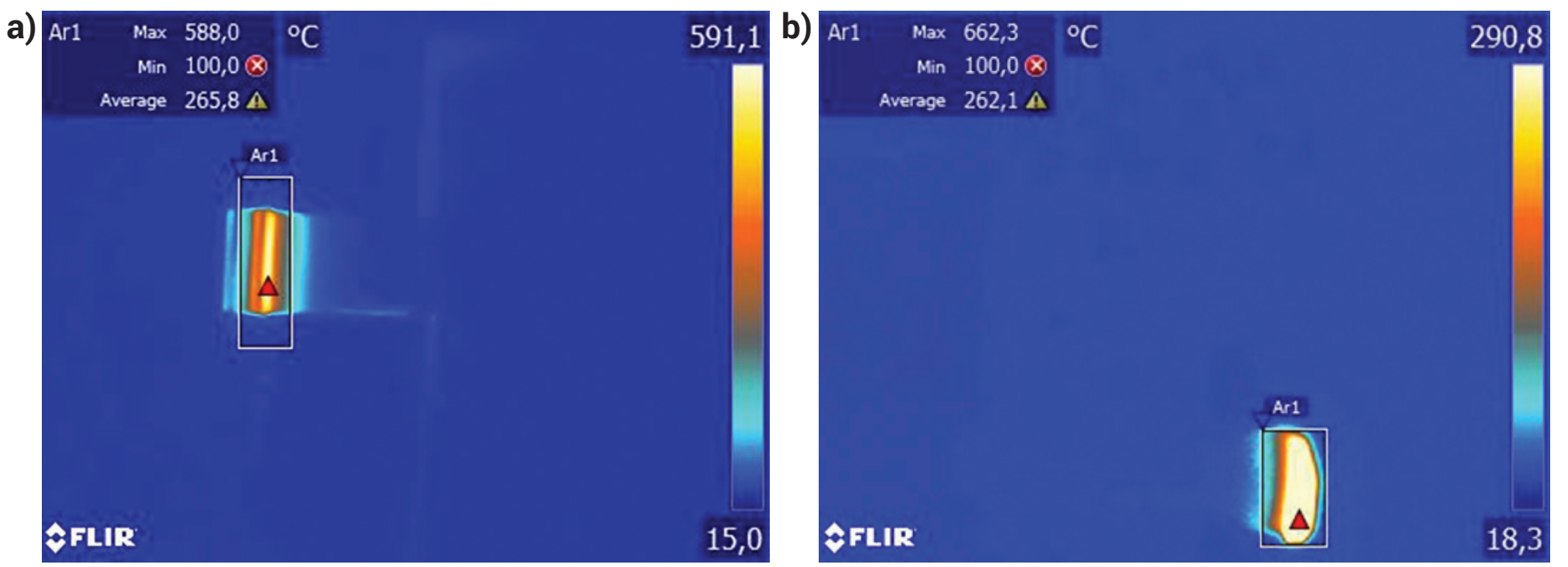

Rys. 12. Temperatura maksymalna zgrzeiny dla próbki $\mathrm{nr} 1$, czas cyklu $-5 \mathrm{~s}$ (a) i próbka $\mathrm{nr} 4$, czas cyklu $-5 \mathrm{~s}$ (b)

Fig. 12. Maximum weld temperature of sample No. 1, cycle time $-5 s(a)$ and sample No. 4, cycle time $-5 s(b)$

\section{Podsumowanie}

Na podstawie analizy wyników otrzymanych z przeprowadzonych badań wynika, że proces trymowania może mieć znaczący wpływ na własności złączy zgrzewanych tarciowo w zależności od materiałów łączonych komponentów. W przypadku rury ciepło odbierane przez kontakt zgrzeiny z nożem i ścięcie gorącej wypływki nie ma wpływu na transformację mikrostruktury oraz wzrost twardości. Natomiast w materiale do ulepszania cieplnego, z którego została wykonana odkuwka, powstałe zmiany są znaczące. Na skutek szybszego chłodzenia zgrzeiny, powstałego podczas procesu usuwania gorącej wypływki, zależnego od dwóch parametrów tj. prędkości obrotowej i ciśnienia posuwu noża w strukturze pojawiają się twardsze niż ferrytyczno-perlityczna struktura materiału fazy martenzytu i bainitu, których ilość jest zależna od prędkości chłodzenia, a więc od parametrów procesu trymowania. W artykule dowiedziono, że wzrost obu z parametrów wiąże się z szybszym chłodzeniem zgrzeiny, a zatem ze wzrostem twardości materiałowej. Zbyt gwałtowny odbiór ciepła może spowodować powstanie bardzo dużego udziału fazy twardego martenzytu, a co za tym idzie - obniżyć własności wytrzymałościowe połączenia i na skutek cyklicznych obciążeń dynamicznych doprowadzić do jego zerwania, które w konsekwencji może spowodować zagrożenie życia osób użytkujących pojazd.

\section{Literatura}

[1] Ambroziak A.: Zgrzewanie tarciowe materiałów o różnych właściwościach, Wydawnictwo Politechniki Wrocławskiej, Wrocław 2011.

[2] Pilarczyk J.: Procesy spajania, Poradnik Inżyniera Spawalnika, tom II, WNT, Warszawa 2005.

[3] Klimpel A.: Spawanie zgrzewanie i cięcie metali. Technologie, Wydawnictwa Naukowo-Techniczne, Warszawa, 1999.

[4] Satyanarayana V.V., Madhusudhan Reddy G., Mohandas T.: Dissimilar metal friction welding of austenitic-ferritic stainless steels, Journal of Materials Processing Technology, Vol. 60, Issue 2, 2005.

[5] Ambroziak A.: Zgrzewanie tarciowe metali trudno topliwych w cieczy na tle innych metod spajania, Prace Naukowe Instytutu Technologii Maszyn i Automatyzacji Politechniki Wrocławskiej, Monografie, 1998.

[6] Ambroziak A.: Dobór warstw przejściowych dla różnoimiennych złączy zgrzewanych tarciowo, Biuletyn Instytutu Spawalnictwa w Gliwicach, R. 43, nr 5, 1999.
[7] Taban E., Gould J.E., Lippold J.C.: Dissimilar friction welding of 6061-T6 aluminum and AISI 1018 steel: Properties and microstructural characterization, Materials \& Design, Volume 31, Issue 5, 2010.

[8] Thomas W.M., Nicholas E.D., Watts E.R., Staines D.G.: Friction Based WeIding Technology for Aluminium, Materials Science Forum, Vols. 396-402, 2002.

[9] Sathiya P., Aravindan S., Noorul Haq A.: Effect of friction welding parameters on mechanical and metallurgical properties of ferritic stainless steel, The International Journal of Advanced Manufacturing Technology, Volume 31, Issue 11-12, 2007.

[10] Maalekian M.: Friction welding - critical assessment of literature, Science and Technology of Welding and Joining, Volume 12, Issue 8, 2007.

[11] Więcek B., De Mey G.: Termowizja w podczerwieni. Podstawy i zastosowania, Wydawnictwo PAK, Warszawa, 2011. 